\title{
DEVELOPMENT OF NANO-ECONOMY AS A FACTOR OF FORMING THE EFFECTIVE NATIONAL INNOVATION SYSTEM OF SINGAPORE
}

\author{
Tetiana Ostapenko \\ Department of Management of Foreign Economic Activity of Enterprises \\ National Aviation University \\ 1 Kosmonavta Komarova ave., Kyiv, Ukraine, 03058 \\ ostapenco@ukr.net
}

\begin{abstract}
The article reveals the theoretical and methodological interpretation of the innovation system, when it determined the structure of the national innovation system. It is noted that the components of the national innovation system are elements, stages and subjects. The main elements are the scientific, technical, production and management. Scientific and technical organization responsible for basic research, applied research implementation and technology transfer from research institutions to production entities. The industrial element is characterized by the implementation of technology in the industry. Management invention provides an element of organizational know-how that would receive revenue from the introduction of the newest technological solutions. Such an approach to the definition of innovation system author used in the analysis of such a system in Singapore. Common indicators confirmed the level of scientific, manufacturing and managerial innovation system segments of Singapore. In statistics of the country, these data are: higher education sector (Science and Technology segment), private sector (commercial segment) and the government sector (management segment). The study concluded that the human factor in a country like Singapore, is the basis of scientific, technical, production and management changes in the development of the national innovation system.
\end{abstract}

Keywords: national economy, national innovation system, elements, stages and subjects of innovation system, nano-technology, nano-economy, a single individual.

\section{Introduction}

Nano-economics is such a system of relations that affects the adjacent system formation. Nano-economy is the economy of human, and the human factor in the development of economic relations today is very important, because decisions on development depends on individuals working independently in enterprises, public authorities and the establishment of international economic organizations. Nano-economy affects the development of the national innovation system, when the research implementations and consumption technology solutions depend on the amplifier of innovation development of national economies. Experience of Singapore, a country without provision of natural resources could achieve intensive development and innovation system and the national economy as a whole, may be indicative not only for Ukraine but also for most countries that develop economic and innovative activity of economic entities.

\section{Analysis of the literature data and the formulation of the problem}

Note that the question of the efficiency and innovation attracted attention of such native and foreign scientists: Ukrainian author [1] who highlighted the essence of the national innovation system; Scientist [2], who focused on the features of formation of innovation system in Ukraine; specialist in the field of innovation [3] who highlighted the national innovation system as an object of state innovation policy; Professor [4], who defined mechanism for the development and commercialization of innovations; author [5], who stated directions of the national innovation system in Ukraine; foreign authors [6], who developed the theory of innovation and innovation systems; British expert [7], who described the development of innovative systems historically; American scientist [8], who made a comparative analysis of national innovation systems; expert in innovation [9], who gave terms of development and implementation of effective innovation. Theoretical and methodological approach to the determination of the national innovation system was borrowed from all these sources. The definition of innovation [10] was the basis of the author's approach. Ukrainian author [2] brought to mind a holistic approach to the formation of innovative systems 
worldwide. Proceedings of the American and British scientists [6-9] became the basis for the use of a system approach to the interpretation of innovation systems at the national level. Ukrainian researcher [3] proposed the approach to identification of innovative component of government policy, and the administrative component of the national innovation system was based on this approach.

\section{The purpose and tasks of the study}

The purpose of the study, the results of which are presented in this article is to determine the factor of the nano-economics in the development of national innovation systems, and the characteristics of the national innovation system to define direction of national economic system as a whole. Can the national economy be effective without innovation activity of economic entities (scientific, technical, production and management)?

To achieve the purpose of the research presented in this article the following taskswill be performed:

1) outline of theoretical approaches to the formation of the national innovation system under the influence of nano-economy;

2) the definition of experience on the development of Singapore's scientific and technical sphere of the national innovation system and its impact on the evolution of the national economy;

3) description of the manufacturing segment of the innovation system of Singapore as a substantial component of the national economy;

4) analysis of administrative areas of Singapore innovation system as the basis of the creation and formation of economic policy;

5 ) the characteristic values of nano-factor for the development of the national innovation system on the example of Singapore.

\section{Materials and methods}

In the article were used materials and statistical data of the Statistical Office of Singapore. Methods used in the study are the following: a systematic approach, structural analysis, surveillance, desk research, comparison, induction and deduction.

\section{The results of the research}

The level of development of society is determined by how it creates and uses technology. Civilization is responsible for manufacturability and performance of production systems, depending on the level of nano-economy, where human depends on growing or active culture and economic activities in the middle of a given economic sector. Scientific and technical relations provide advanced features of competitiveness of national economies and their component - national innovation system.

Innovation system is very complex entity which forms the country's innovation system, which, in turn, is determined by a number of features.

The core of the innovation system is an innovative activity. Innovation activity - it is a state of the economic environment state institutional framework which is science and technology, production and management system. The innovative system exists in all countries; the condition of its operation is a clear number of scientific studies that link the integrity of certain artists, researchers and implementers.

Evaluation of innovative system provides an analysis of its components as elements, stages and subjects.

Innovative system covered the entire process - from the birth of scientific idea to its implementation in production. This process is gradually formed in various areas - science and technology, production and management. All these areas are consistent components of a single process, and therefore - the elements of the innovation system [11].

Science and technology, as the part of an innovative system has research function, which is represented by such activities as basic and applied research and development. 
A special characteristic of scientific and technical sphere country's innovation system is the number of scientific and technological inventions. The level of patenting is an important indicator of innovative system and economy and science in the country as a whole.

Note that most of the operations of scientific and technological exchange is a transaction that determines the transfer of modern technologies of production of goods and services. Production technology is also being implemented within the innovation system - namely in production.

The feature of the production sector is that technology, as an expression of the body of knowledge, gains materialized form. This area formed a number of activities that are gradually following one another: development, testing, leasing, training pilot production, preparation production. According to the definition [10], such materialized scientific and technological products are innovations. Moreover, the result of the production sector of innovation system of the country is innovation. Innovations are divided into: innovations, products and innovation processes.

Management sector of innovation system represented the control element of scientific, technical and industrial fields. The effectiveness of the management of these areas is shown in the specificity and effectiveness of those elements of the innovation system of any country.

Content of the technological changes that occur in all areas of the innovation system, is characterized by a certain stage as innovation system [4].

The stages of the innovation system are the stages of the innovation cycle. The innovative cycle consists of two phases:

1) create technology that involves the invention of new technologies that can be applied in specific research and development of new products or processes. This phase involves two stages scientific and technological;

2) introduction of innovations in production, providing financial implementation of knowledge production. Stages - industrial and consumer.

Implementation of technological and innovation challenges involves the passage of enterprises of different stages of the innovation cycle. Providing such movement takes place in various regions of the innovation system.

The subjects of the innovation system can be carriers of such functions as research, engineering, manufacturing and management. Depending on the performance of certain types of actors in the innovation system the different groups are united:

- scientific, technical, conducting technical research activities and the operation of the relevant areas of the innovation system;

- production, characterized by the fact that they are designed to introduce new products and production processes;

- management systems provide innovative subjects planned, organizational and control functions of the innovation system and make its administrative area.

The most common among the scientific and technical subjects is higher education, such as universities, which in addition to the educational function have significant research potential [1].

Industrial actors transform the technology innovation. The main actors are among the production companies that fall into two categories: innovation and non-innovation ones. Innovative enterprise - a company that is institutionally divided into external and internal.

One of the main functions of management innovation system are funding research and development (R\&D), carried out by various scientific and technical institutions.

Funding of R\&D [4] takes different forms, which are both forms of the science and technology activities as the part of the innovation system. Financing the production sector makes them implemented in production innovation - business structures (different activity from mineral exploration to finance marketing activities).

Using the innovative features of the system, let's describe the development of this system in Singapore.

Singapore, South-East Asia, active development of which began in the late $70 \mathrm{~s}$ and mid- $80 \mathrm{~s}$ of the twentieth century. This country was called one of the Asian dragons (or tigers), along with Hong Kong, Taiwan and South Korea. This term was used because these countries rapidly turned from the developing countries to developed economies. And such a development relies on active 
innovation when the developed countries were involved in the technology and introduced new business. These countries have created a line of innovative development, which began to be called «progressive assembly» when imported spare parts, businessmen of these countries dealt with ready, mostly machine-technical, production, and subsequently began to make their own, authentic, so created Hyundai and KIA, etc.

Singapore - is a small country that has built on this principle its innovative system, which consists of scientific and technological sector, production and management. Let's consider them gradually.

So, Singapore stats gives data on the organization of work on R\&D by sector from 1990 to 2014 .

Table 1 presents information on the number of performed work in sectors such as:

- private (involves the development of innovative enterprises);

- higher education;

- government;

- public research institutes.

Table 1

Organization of R\&D by sectors (number of cases execution of works)

\begin{tabular}{|c|c|c|c|c|c|c|c|}
\hline Sphere & 1990 & 2000 & 2010 & 2011 & 2012 & 2013 & 2014 \\
\hline Total & 292 & 582 & 859 & 864 & 758 & 873 & 950 \\
\hline - private sector & 266 & 539 & 799 & 804 & 699 & 812 & 882 \\
\hline - higher educational establishments & 5 & 6 & 11 & 11 & 12 & 13 & 12 \\
\hline - government sector & 14 & 24 & 29 & 29 & 28 & 29 & 31 \\
\hline - public research institutes sector & 7 & 13 & 20 & 20 & 19 & 19 & 25 \\
\hline
\end{tabular}

Source: [12]

The dynamics is clear exactly when private enterprise sector is a major player in the innovation system in Singapore that is a positive development, because the company is the vanguard of technological development in the world. The industrial segment of the innovation system of Singapore takes the lion's share of research and development of the State.

Pay attention to the number of executed research universities for such a small state (12th in 2014.) And research institutions (25th in 2014) are the significant indicator, and thus confirms the development of scientific and technical segment of the innovation system of the country.

Management sector of innovation system is introduced by government programs, which implementation has increased from 14 operations in 1990 to 31 case in 2014 (growth twice in 24 years).

The statistics of Singapore shows that the country's innovation system exists, because of all work performed on all types of existing entities that perform innovation - scientific and technical subjects, production and management entities.

The research works and innovative development of innovation system of the country is determined by the quality and quantity of scientific and technical personnel involved in the innovation process. Table 2 shows the labor force and its qualitative composition, which is involved in the innovative development of the country.

In 2014, as the Table 2 demonstrates, the total number of scientific workers was 47,902 people, which is almost three times more than in 1997. For Singapore is a great performance. These scientists are engaged in various innovative institutions of the country - from research institutes to small innovative businesses.

Total male scientists are more than two total female scientists. Unlike the maintenance staff, where the number of women exceeds the number of male staff. Note that future innovation system of the country depends on the activity of young people in scientific field of the country, the number of postgraduate full-time in Singapore in 2014 is 5800 people, which is almost twice more than in 2000. Research area is also popular for staff: workers without a degree, technicians and supporting staff. So the number corresponds to the main indices in other countries, and is accordingly: 2095, 3083 and 4089 in 2014. 
Table 2

Employees of R\&D in Singapore

\begin{tabular}{cccccccc}
\hline Categories of employees & $\mathbf{1 9 9 7}$ & $\mathbf{2 0 0 0}$ & $\mathbf{2 0 1 0}$ & $\mathbf{2 0 1 1}$ & $\mathbf{2 0 1 2}$ & $\mathbf{2 0 1 3}$ & $\mathbf{2 0 1 4}$ \\
\hline Total & 17219 & 25220 & 43164 & 44855 & 45001 & 47275 & 47902 \\
Total of men & - & - & 28796 & 29942 & 29977 & 31608 & 31875 \\
Total of women & - & - & 14368 & 14913 & 15024 & 15667 & 16027 \\
Scientific researchers and engineers & 11302 & 14483 & 28296 & 29482 & 30109 & 31943 & 32835 \\
Men & - & - & 20531 & 21345 & 20647 & 22665 & 23319 \\
Women & - & - & 7765 & 8137 & 8462 & 9078 & 9516 \\
Graduate students in full-time studying & - & 3819 & 5760 & 5990 & 5924 & 6012 & 5800 \\
Men & - & - & 3618 & 3752 & 3710 & 3852 & 3703 \\
Women & - & - & 2142 & 2238 & 2214 & 2160 & 2097 \\
Researchers without scientific degree & 2039 & 2498 & 2505 & 2541 & 2399 & 2430 & 2095 \\
Men & - & - & 1700 & 1813 & 1709 & 1712 & 1456 \\
Women & - & - & 805 & 728 & 690 & 718 & 639 \\
Technical personnel & 2297 & 2262 & 3101 & 3089 & 3022 & 3115 & 3083 \\
Men & - & - & 1867 & 1872 & 1807 & 1900 & 1921 \\
Women & - & - & 1234 & 1217 & 1215 & 1215 & 1162 \\
Supporting personnel & 1581 & 2158 & 3502 & 3753 & 3547 & 3775 & 4089 \\
Men & - & - & 1080 & 1160 & 1104 & 1279 & 1476 \\
Women & - & - & 2422 & 2593 & 2443 & 2496 & 2613
\end{tabular}

Source: [12]

Thus, Singapore's innovation system is equipped with scientific and technical personnel of various scientific level (from the professors to the laboratory workers).

To explore innovative system, R\&D expenditure of the country must be estimated. These data are given by the Statistical Office of Singapore. Consider gradually the indices of total costs, the costs for private sector (innovative enterprises), the costs for higher education, the cost for the public sector and public research institutes. So, the Table 3 covers costs for research and development in various sectors.

Table 3

Total expenses on R\&D in Singapore (mln. USD)

\begin{tabular}{cccccccc}
\hline Spheres of national economy & $\mathbf{2 0 0 0}$ & $\mathbf{2 0 0 5}$ & $\mathbf{2 0 1 0}$ & $\mathbf{2 0 1 1}$ & $\mathbf{2 0 1 2}$ & $\mathbf{2 0 1 3}$ & $\mathbf{2 0 1 4}$ \\
\hline Total expenses & 3009,5 & 4582,2 & 6489,0 & 7448,5 & 7244,7 & 7565,8 & 8526,5 \\
Agriculture and food production & 29,7 & 52,2 & 111,6 & 155,2 & 200,0 & 210,3 & 262,4 \\
Engineering and Technology & 1543,8 & 2597,4 & 3958,1 & 4675,1 & 4501,8 & 4614,4 & 5052,1 \\
$\quad$ Biomedical Sciences & 145,5 & 853,4 & 1360,7 & 1372,8 & 1404,1 & 1367,7 & 1578,1 \\
Natural sciences & 247,6 & 459,2 & 705,4 & 843,4 & 834,6 & 881,4 & 1103,2 \\
The energy sector & - & - & - & 81,0 & 101,8 & 108,1 & 122,4
\end{tabular}

Source: [12]

Total R\&D spending increased by fourteen years in 2,5 times. The basic amount of the cost falls on the field of engineering and manufacturing processes. Biomedical Science has the second 
position after engineering, note that biomedicine increased the costs for the same fourteen years in 10 times. Today it is concentrated in biomedicine major nano-researches. A graduates number is the largest in this area. Intensively development of energy research began in 2011, and its financing increased almost double by 2014.

R\&D expenses are determined by the object of investing. The statistics is determined by the capital costs, personnel costs and other operating costs. General information on R\&D expenditure in Singapore on the type of value is presented in Table 4.

Table 4

Total R\&D expenditures by type of cost (mln. USD)

\begin{tabular}{|c|c|c|c|c|c|c|c|}
\hline Type of costs & 2000 & 2005 & 2010 & 2011 & 2012 & 2013 & 2014 \\
\hline Total & 3009,5 & 4582,2 & 6489,0 & 7448,5 & 7244,7 & 7565,8 & 8526,5 \\
\hline 1) the cost of capital: & 562,9 & 798,0 & 967,7 & 895,6 & 1141,3 & 1004,4 & 1256,7 \\
\hline - land, buildings, other structures & 54,0 & 139,9 & 119,7 & 144,5 & 209,2 & 261,2 & 274,8 \\
\hline - cars, machinery, equipment & 508,9 & 658,1 & 848,0 & 751,1 & 932,1 & 743,2 & 981,9 \\
\hline 2) cost of Labor: & 1256,2 & 1937,5 & 2860,4 & 3436,2 & 3308,1 & 3475,7 & 3805,3 \\
\hline - researchers: & 1078,8 & 1647,0 & 2463,6 & 2888,9 & 2869,8 & 3057,3 & 3360,9 \\
\hline - researchers, scientists, engineers & 957,7 & 1433,0 & 2200,4 & 2331,8 & 2579,6 & 2754,6 & 3073,1 \\
\hline - graduate students full-time of stufying & 18,7 & 62,5 & 136,4 & 144,4 & 146,3 & 154,0 & 154,8 \\
\hline - the researchers without a scientific degree & 102,4 & 151,5 & 126,9 & 412,7 & 143,9 & 148,7 & 133,0 \\
\hline - techniques & 69,3 & 109,1 & 170,2 & 198,2 & 160,4 & 165,2 & 152,4 \\
\hline - other & 108,0 & 181,3 & 226,6 & 349,2 & 277,9 & 253,2 & 292,0 \\
\hline 3) cost of other operating expenses & 1190,4 & 1846,8 & 2661,0 & 3116,7 & 2795,4 & 3085,7 & 3464,4 \\
\hline
\end{tabular}

Source: [12]

Table 4 shows that the biggest share of the cost of R\&D accounts are used for payment of labor, as scientists around the world are employees with the highest salaries. But scientists without financial support are not able to carry out research at a high level. Therefore, the cost of equipment and machinery is also the main categories of total expenditure for R\&D in Singapore. Other operating costs are also significant.

Obviously, the country's innovation system can not exist without significant investments and in Singapore they are increasing. So the total cost of R\&D and innovation system of the country increased almost three times in fourteen years from 2000 to 2014 and as the result improved the situation of researchers and graduate students by scholarships and gradually increased salaries. The individual researcher as the main subject of nano-economy in a country like Singapore is in a comfortable position, and the state respects his needs and requirements.

Common indicators confirmed the level of scientific, manufacturing and managerial innovation system segments of Singapore. In statistics of the country, these data are: higher education sector (Science and Technology segment), private sector (commercial segment) and the government sector (management segment).

So, focus on the higher education sector. Table 5 shows the cost in Singapore for innovation in the universities of the country.

Table 5 shows that the higher education of Singapore is actively pursuing innovative research. Overall R\&D spending at universities in the country from 2000 to 2014 increased four times. The most active sector of university research is the engineering and production technology. Actively growing costs (6.5 times) for research in the biomedical sciences prove that the country is trying to be a leader in this field. General trend of higher education meets a national orientation. Note that the cost of biological research are increasing worldwide and the global markets biotechnology, including nano are emerging. Singapore in this area is one of the leading countries of the world. 
Table 5

Spending on R\&D in universities of Singapore (mln USD)

\begin{tabular}{cccccccc}
\hline Fields of national economy & $\mathbf{2 0 0 0}$ & $\mathbf{2 0 0 5}$ & $\mathbf{2 0 1 0}$ & $\mathbf{2 0 1 1}$ & $\mathbf{2 0 1 2}$ & $\mathbf{2 0 1 3}$ & $\mathbf{2 0 1 4}$ \\
\hline Total innovation expenditures in universities & 338,3 & 478,0 & 368,1 & 1086,4 & 1192,7 & 1311,3 & 1349,3 \\
Agriculture and food production & 1,1 & 1,0 & 1,3 & 2,1 & 8,0 & 7,4 & 13,0 \\
Engineering and Technology & 166,4 & 190,3 & 380,4 & 340,6 & 418,8 & 477,4 & 472,7 \\
Biomedical Science & 56,5 & 131,9 & 250,9 & 288,0 & 310,7 & 336,6 & 366,1 \\
Natural sciences & 61,2 & 94,3 & 197,9 & 292,4 & 286,8 & 316,5 & 307,9 \\
The energy sector & - & - & - & 72,4 & 86,8 & 88,2 & 103,1 \\
Other & 23,4 & 60,5 & 137,6 & 90,9 & 81,7 & 88,2 & 86,6
\end{tabular}

Source: [12]

Also, focus on the classification of costs according to the investment objectives of these expenses in the segment of higher education. These data are shown in Table 6.

Table 6

Expenses of universities on R\&D by type of cost (mln. USD)*

\begin{tabular}{lccccccc}
\hline \multicolumn{1}{c}{ Type of costs } & $\mathbf{2 0 0 0}$ & $\mathbf{2 0 0 5}$ & $\mathbf{2 0 1 0}$ & $\mathbf{2 0 1 1}$ & $\mathbf{2 0 1 2}$ & $\mathbf{2 0 1 3}$ & $\mathbf{2 0 1 4}$ \\
\hline Costs in the universities of the country: & 338,3 & 478,0 & 968,1 & 1086,9 & 1192,7 & 1311,3 & 1349,3 \\
1) the cost of capital: & 60,2 & 75,6 & 126,5 & 128,3 & 145,1 & 175,7 & 171,3 \\
- land, buildings, other structures & 0,0 & 16,5 & 5,2 & 7,0 & 18,2 & 12,9 & 1,7 \\
- cars, machinery, equipment & 60,2 & 59,1 & 121,3 & 121,2 & 126,9 & 162,7 & 169,6 \\
2) cost of Labor: & 233,1 & 284,2 & 562,5 & 629,3 & 691,4 & 764,9 & 799,6 \\
- researchers: & 212,2 & 262,1 & 513,0 & 571,3 & 625,2 & 690,0 & 722,7 \\
- researchers, scientists, engineers & 192,5 & 198,4 & 375,1 & 423,8 & 476,2 & 533,1 & 565,0 \\
$\quad$ - graduate students full-time of studying & 18,7 & 62,5 & 136, & 144,4 & 146,3 & 154,0 & 154,8 \\
$\quad$ - the researchers without a scientific degree & 1,0 & 1,2 & 1,5 & 3,2 & 2,8 & 2,9 & 2,9 \\
- techniques & 10,8 & 12,5 & 14,9 & 15,3 & 16,4 & 19,0 & 16,9 \\
- other & 10,1 & 9,7 & 36,6 & 42,7 & 49,7 & 55,9 & 59,9 \\
3) cost of other operating expenses & 45,0 & 118,2 & 279,1 & 328,9 & 356,2 & 370,7 & 378,4
\end{tabular}

Source: [12]

The table shows that the Singapore overall cost system spends significant funds to support scientific and maintenance staff, for payment of labor and researches at the universities. And graduate students are also intensively supported as the future of innovation system. Certainly invested funds and equipment are the needed basis for research. Movable and immovable property as an indicator of the innovation system.

The industrial segment of the innovation system of the country is also developing quite rapidly, that is certified by the Table 7 .

Table 7 shows that the costs of the private business sector of innovation system in Singapore almost tripled for fourteen years. Entrepreneurs invest in innovation on the environment, which involves setting up treatment plants at existing factories of the real sector of 
economy. But the greatest amount of money are spent on accounting system of engineering and development processes at their enterprises. The practice of improving biotechnology is also developing.

The cost structure of the business sector in the country is shown in the Table 8 .

Table 7

The cost of the private manufacturing sector in Singapore on R\&D (mln USD)

\begin{tabular}{cccccccc}
\hline The scope of the national economy & $\mathbf{2 0 0 0}$ & $\mathbf{2 0 0 5}$ & $\mathbf{2 0 1 0}$ & $\mathbf{2 0 1 1}$ & $\mathbf{2 0 1 2}$ & $\mathbf{2 0 1 3}$ & $\mathbf{2 0 1 4}$ \\
\hline Total costs of innovative enterprises & 1866,0 & 3031,3 & 3947,6 & 4628,2 & 4415,2 & 4496,1 & 5215,7 \\
Agriculture and food production & 6,4 & 43,5 & 97,2 & 137,0 & 180,1 & 178,7 & 226,5 \\
Engineering and Technology & 983,2 & 1971,1 & 2904,7 & 3250,0 & 3319,1 & 3326,4 & 3629,1 \\
Biomedical Science & 42,0 & 298,5 & 642,3 & 517,2 & 502,6 & 431,1 & 523,6 \\
Natural sciences & 81,0 & 258,1 & 363,5 & 372,3 & 371,7 & 396,9 & 613,9 \\
The energy sector & - & - & - & 7,7 & 14,4 & 19,3 & 19,3 \\
Other & 302,3 & 460,1 & 40,0 & 73,9 & 27,4 & 143,8 & 203,2
\end{tabular}

Source: [12]

\section{Table 8}

The cost of the private business sector on R\&D in Singapore by type of cost (mln. USD)

\begin{tabular}{lccccccc}
\hline \multicolumn{1}{c}{ Types of expenses } & $\mathbf{2 0 0 0}$ & $\mathbf{2 0 0 5}$ & $\mathbf{2 0 1 0}$ & $\mathbf{2 0 1 1}$ & $\mathbf{2 0 1 2}$ & $\mathbf{2 0 1 3}$ & $\mathbf{2 0 1 4}$ \\
\hline Costs in the private sector of the country: & 1866,0 & 3031,3 & 3947,6 & 4628,2 & 4415,2 & 4496,11 & 5215,7 \\
1) the cost of capital: & 363,2 & 492,3 & 618,6 & 467,7 & 807,9 & 662,4 & 902,6 \\
- land, buildings, other structures & 47,7 & 63,9 & 68,0 & 92,0 & 156,6 & 196,7 & 231,8 \\
- cars, equipment, machinery. & 315,5 & 428,4 & 550,6 & 375,7 & 651,3 & 465,7 & 670,8 \\
2) cost of Labor: & 693,6 & 1252,3 & 1640,9 & 2088,1 & 1859,7 & 1884,7 & 2124,9 \\
- researchers: & 604,1 & 1064,7 & 1452,4 & 1774,6 & 1640,9 & 1709,6 & 1914,6 \\
- researchers, scientists, engineers & 516,4 & 919,5 & 1335,3 & 1387,1 & 1504,5 & 1372,7 & 1791,2 \\
$\quad$ - graduate students full-time of studying & 0 & 0 & 0 & 0 & 0 & 0 & 0 \\
$\quad$ - the researchers without a scientific degree & 87,7 & 145,2 & 117,1 & 387,5 & 131,4 & 136,9 & 123,4 \\
- techniques & 35,7 & 62,7 & 70,8 & 103,3 & 71,6 & 70,3 & 75,7 \\
- other & 53,8 & 124,9 & 117,8 & 210,3 & 147,2 & 104,8 & 134,5 \\
3) cost of other operating expenses & 809,2 & 1286,8 & 1688,1 & 2072,4 & 1747,6 & 19449,0 & 2188,2
\end{tabular}

Source: [12]

Traditionally the Table 8 shows that the largest number of business spending is allotted to pay for labor, other operating expenditures and to pay the cost of capital, such as buildings and equipment for researches and their implementation into life. Obviously, not all graduate students are employed at enterprises of the country, but according to the Singapore media, they practice at these enterprises and are arranged to work for them after receiving the degree. Note also that the business sector of Singapore innovation system accumulates in 3.8 times more money than university technological component. Enterprises are the leading element of the innovation system.

Management sector of innovation system in Singapore is characterized by its supporting costs in different areas of research. This information is shown in the Table 9. 
Table 9

Expenses of Singapore government sector on R\&D (mln USD)

\begin{tabular}{ccccccccc}
\hline Fields of national economy & $\mathbf{2 0 0 0}$ & $\mathbf{2 0 0 5}$ & $\mathbf{2 0 1 0}$ & $\mathbf{2 0 1 1}$ & $\mathbf{2 0 1 2}$ & $\mathbf{2 0 1 3}$ & $\mathbf{2 0 1 4}$ \\
\hline Total innovation expenditures Government & 423,8 & 442,8 & 672,3 & 758,3 & 725,0 & 857,6 & 972,1 \\
Agriculture and food production & 1,6 & 5,4 & 13,1 & 16,0 & 11,9 & 18,7 & 18,6 \\
Engineering and Technology & 229,5 & 246,9 & 329,6 & 360,2 & 341,7 & 400,5 & 482,0 \\
Biomedical Science & 32,5 & 116,7 & 152,7 & 179,7 & 182,1 & 198,3 & 254,1 \\
Natural sciences & 32,1 & 62,6 & 76,6 & 107,6 & 97,1 & 89,8 & 102,3 \\
The energy sector & - & - & - & 0,6 & 0,7 & 0,6 & 0,0 \\
Other & 41,3 & 10,6 & 100,2 & 94,0 & 91,5 & 149,6 & 115,2
\end{tabular}

Source: [12]

Table 9 shows that innovation costs of Government in Singapore for 14 years almost doubled. The basic amount of the cost falls on the engineering and biomedical sciences. As it was shown in previous research, Singapore innovation system depends on research in these sectors. The innovative features of Singapore depends on the nano-level national economy when Singapore scientists and engineers realize the certain innovative solutions.

\section{Discussion of results}

It should be noted that the advantage of this study is to use a systematic approach to the interpretation of the innovation system. The disadvantages of the article is that the value coexistence of national innovation system and its international level is not defined. The diffusion conditions of technology and innovation at the national and international environment are not covered. The conditions are not the commercialization of new innovative solutions. Note that the results of this study can be applied at assessing the effectiveness of the national innovation system of any countries, including Ukraine. We emphasize that this study is a continuation of the analysis of national innovation systems and nano-economy. Evaluation of nano-economics is the newest area of research of economic systems that can get progress in further studies of various scientists.

\section{Conclusions}

During the study there were made the following conclusions:

1) national innovation system is defined as a set of interconnected elements and stages that determined the development of nano-factor;

2) science and technology innovation system in Singapore is determined by the active development of research in engineering and the direction in biomedical analysis;

3) manufacturing sector is characterized by the considerable business activity in the development and introduction of new innovative solutions;

4) management area of research is characterized by the significant costs and support of scientific, technological and industrial sectors of the innovation system;

5) all aspects of the innovation system in Singapore are affected by human factor (factor of nano-economy), when some graduate students, engineers and doctors are supported by the state and influence the research, production and management functions of the national innovation system in Singapore.

It should be emphasized that the human factor plays a special role in forming the innovation system in Singapore, where scientists and entrepreneurs who develop and implement innovations are actively supported.

The funds accumulated in the state budget are spent actively for innovation policy and support industries of leading innovation system (to support graduate students as the future of the system of updating and innovative companies in the country that is very interested in the latest transformations). 


\section{References:}

[1] Bunyak, N. M. (2007). Sutnist nacionalnoyi innovacijnoyi systemy. Efektyvna ekonomika, 7. Available at: http://www.economy.nayka.com.ua/?op=1\&z=633

[2] Yaremko, L. (2007). Nacionalna innovacijna systema ta yiyi formuvannya v Ukrayini // Formuvannya rynkovyh vidnosyn v Ukrayini, 1, 54-57. Available at: http://lukyanenko.at.ua/_ld/6/696 .pdf

[3] Fedirko, O. (2007). Nacionalna innovacijna systema yak ob’yekt derzhavnoyi innovacijnoyi polityky. Mizhnarodna ekonomichna polityka, 1(6), 63-88. Available at: http://www.iepjournal.com/journals/6/2007_03_Fedirko.pdf

[4] Antonyuk, L. L., Poruchnik, A. M., Savchuk, V. S. (2003). Innovaciyi: teoriya, mehanizm rozrobky ta komercializaciyi. Kyiv: KNEU, 28

[5] Karpenko, A. V. (2013). Formuvannya ta rozvytok nacionalnoyi innovacijnoyi systemy Ukrayiny. Zbirnyk naukovyh pracz Tavrijskogo derzhavnogo agrotehnologichnogo universytetu (ekonomichni nauky), 1 (2), 102-115.Available at: http://nbuv.gov.ua/UJRN/znptdau_2013_1_2_15

[6] Lundvall, B-A. (Ed.) (1992). National Innovation Systems: Towards a Theory of Innovations and Interactive Learning. London: Pinter, 317.

[7] Freeman, C. (1995). The National System of Innovation in Historical Respective. Cambridge Journal of Economics, 19 (1), 5-24.

[8] Nelson, R. R. (Ed.) (1993). National Innovation Systems. A comparative Analysis. New York: Oxford University Press, 560.

[9] Rothwell, R. (1992). Successful industrial innovation: critical factors for the 1990s. R\&D Management, 22 (3), 221-240. doi:10.1111/j.1467-9310.1992.tb00812.x

[10] Shumpeter, J. (1982). Teorija ekonomicheskogo razvitija. Moscow: Progress, 400.

[11] Ostapenko, T. G. (2012). Mizhnarodnyj obmin tehnologiyamy u formuvanni konkurentnyh perevag nacionalnoyi ekonomiky (na prykladi Italiyi). Kyiv: Zovnishnya torgivlya, 188.

[12] Department of statistics Singapore. Available at http://www.tablebuilder.singstat.gov.sg 